\title{
User Interface Review on Digital Magazine: A Case Study on Femina
}

\author{
Ariani Wardhani \\ School of Design and Creative Art, Universitas Mercu Buana, Indonesia
}

\begin{abstract}
Femina is one of the most prominent magazines in Indonesia. Through Femina, the Indonesian women attain information in delivering the fashion trend that has been developing in accordance to the turn of the century. In 2011, Femina has been transformed from the conventional magazine to the digital magazine. One of the easiness that the readers might enjoy from the transformation is related to the user interface design of the digital magazine. The presence of the user interface in the digital magazine has encouraged the researcher to conduct a study on the user interface since it has been believed that the female readers of the digital magazine are able to operate the user interface easily. With regards to the statement, the results of the analysis within the study might be benefitted for developing the user interface design in the digital magazine, especially for Femina, so that the readers will be more facilitated in operating the digital magazine application. Within the conduct of the study, the researcher has implemented the qualitative method. In addition, the data for the study had been gathered by means of quantitative method in order to attain the necessary elements of user interface for creating the layout that might have been desired by the readers of the Femina digital magazine.
\end{abstract}

Keywords: female, magazine, user interface, digital

DOI: $10.7176 / \mathrm{ADS} / 76-01$

Publication date:September $30^{\text {th }} 2019$

\section{Background}

One of the familiar media as information source and also entertainment source is magazine. According to Santana (2005:93-97), magazine has been one of the information sources that have had market segment in the public. The reason is that magazine has been focused on the homogenous groups which, certainly, have similar interest; as a result, the marketing in that industry might be targeted to certain taste or domain. The presence of targeted segment might be benefitted easily for drawing the public attention in the geography level, the social level, the income level and the education level. Therefore, public might choose magazine as the information source in accordance to the individual needs.

Up to date, people still sense that magazine plays a vital role. The presence of the vital role in the magazine might be traced from the appearance of numerous new magazines in Indonesia. The development of the magazine, especially for the female one, has focus on the lifestyle. The number of circulating female magazine in Indonesia proves that Indonesian females have put high interest on the magazine. Then, the female magazines that have still been in circulation are namely: Bazaar, Femina, Marie Claire, Kartini, Her World, Dewi, Grazia, Female, Elle, Cosmopolitan and more. Most of Indonesian women have decided to attain information from female magazines because they are aware of the importance of lifestyle.

Women are potential market share and in the same time magazines are more open to the female readers than newspapers are. According to Biagi (2010:94-95), magazine becomes an important instrument in pursuing social changes. The reason is that since the beginning of the magazine publication women are the best readers. Furthermore, the female readers want to attain specific information that they might not attain from other sources.

In the practice, the employment that has been occupied by the Indonesian women ranges from officials, businesswomen, employees and even housewives. Despite these employments, the Indonesian women are always eager to learn about their surroundings. Not to mention, the variability of the employment has made them aware of attaining information. In the same time, the demand toward the socio-cultural life, the lifestyle and the interaction with other people has caused the Indonesian women to find the latest information with regards to their life.

One of the magazines that have been long-lasting in Indonesia up to date is Femina. Through Femina Magazine, the Indonesian women attain information in relation to the fashion trend that has been progressing in accordance to the turn of the age. The self-appearance of the Indonesian women might be reflected through the "Fashion" rubrics that have been developing within the magazine since these rubrics have been mostly awaited by the Indonesian women consistently. Since its establishment in 1972, the "Fashion" rubrics in Femina has always been in presence and delivers the fashion development of the Indonesian women. In the same time, the "Fashion" rubrics also share information and open the horizon for the readers.

In 2011, Femina Magazine launched the digital version of the lifestyle magazine. The launch of the digital lifestyle magazine does not only change the layout of the media but also the reading habit toward the media. The change indeed has impacts on the urban women who live in Jakarta as the target readers of the magazine. The 
digital lifestyle magazine that has benefitted the latest technology provides ease of use and practicality for these women. In relation to the statement, nowadays many computer products have been introduced specifically by several companies for the reading activities and one of these products is the Tablet Computer. In the daily activities, the tablet computer is more suitable for reading e-book and digital magazine, playing games and also opening social networks and e-mail.

Departing from the previous elaboration, it is clear that there are differences between the digital magazine and the printed magazine. One of the differences lay in the user interface design; the user interface design has assisted the readers to easily read the digital magazine and thus reading the digital magazine becomes more practical that reading the printed magazine. According to Mikhail Bakhtin (Baxter, 2004: 182-192), a contradictive relationship between the analogue pattern and the digital pattern refers to the contradiction between the desire and the needs in the relational communication within human beings. This relationship provides contradictory impulses to the readers, specifically the female readers of Femina Magazine in Jakarta. Eventually, this relationship has impacts on the user interface design of the Femina Digital Magazine among the Indonesian women as they read the magazine in its digital form. This problem has encouraged the researcher to conduct a study in order to identify the components of the user interface design that might be user-friendly for the female Indonesian magazine readers. Departing from the statement, it is expected that the results of the analysis within the study might be benefitted for developing more user-friendly user interface design in the digital magazine, especially for the Femina Digital Magazine, so that the readers might be easily assisted in using the application of digital magazine.

\section{Literature Review}

User interface (UI) design is a term that has been used for describing the layout of a machine or a computer unit that has direct interaction with the user. The design and the draft of the user interface should be given special attention in order that the user interface will draw the interest of the user. Schlatter (2013) provides a number of guidelines for designing an application that might be user-friendly by dividing the guidelines into several useful components as follows:

a. Consistency

Consistency refers to the consistency of the user interface layout.

b. Hierarchy

Hierarchy refers to the arrangement of the hierarchy of interest from the objects that will be contained in the application.

c. Personality

Personality refers to the first impression that has been apparent from the application and the first impression will display the peculiar characteristics of the application.

d. Layout

Layout refers to the position of the elements within an application.

e. Type

Type refers to the typography that has been implemented within an application.

f. Colour

Colour refers to the appropriate use of colours for an application.

g. Imagery

Imagery refers to the use of figures, icons and alike for delivering the information within an application.

h. Control and Affordances

Control and Affordances refers to the elements of the user interface that might be implemented by the users to interact with the system through a screen.

The manual for the manufacture of user interface design within a mobile application will be different from one device to another depending on the running operating system. Specific to the study, the application that will be selected is the Apple-based application. Therefore, the reference for the manufacture of the user interface in the study is the principle of IOS X design or more popularly known as Human Interface Guidelines.

Many studies have been conducted in relation to user interface. However, a case study for the digital magazine should be conducted because the user interface in the digital magazine might influence the readership of the Indonesian women. Not to mention, the readership between the Indonesian men and the Indonesian women; consequently, the reading habit and culture will be different. Then, the present case study on the analysis of user interface has several interrelated references, for example:

a. Naufal (2018) has conducted a study under the following title: "Analysing the Components of Layout Design, Colour and Control on the User Interface of Mobile Application Based on the User-Friendliness." The study focuses on the identification of user interface design for the user-friendly mobile application.

b. Nurlifa et al. (2014) has conducted a study under the following title: "Analysing the Influence of User Interface on User-Friendliness of Decision Support System Use for a Doctor." The study focuses on the 
usability of the user interface as the basis of use for the doctor in operating the decision support system.

c. Govindarajan (2011) has conducted a study under the following title: "General Principles of User Interface Design and Website." The study provides the general principles of user interface design and their relevance for the modern web interface with thorough analysis. The investigation of each principle in the study consists of five types of web interface with different 30 web sites for each type. In the same time, numerous properties that have contribution on the principles are also investigated thoroughly and the results of the investigation are reported in statistical values.

\section{Method}

Within the conduct of the case study, the researcher implemented the qualitative methodology with the quantitative data gathering activities in order to attain the user interface that might be appropriate for the readers of the digital magazine.

\subsection{Approach}

The approach that had been implemented in the case study was the cultural studies approach. The cultural studies approach had been implemented because through this approach the researcher would like to explore the understandable intercultural relationship as part of expressive activities and peculiar life from a community. Within the implementation of the cultural studies approach, the researcher combined two disciplines, namely the design discipline and the social discipline, in order to attain a review on the culture of urban women identity in Indonesia. Then, the discussions within the case study referred to the cultural study in the perspective of the shift from the printed media to the digital media in the aspect of cultural perspective through the media reality. Specifically, through the conduct of the case study on the Femina Digital Magazine the researcher would like to view the perspective of the urban women identity and representation in Jakarta as they dealt with the shift from the printed media to the digital media. According to Barker (1998:8-12), representation and identity are two keywords in cultural studies.

\subsection{Data Source and Data Gathering Technique}

The quantitative data gathering activities were performed in order to attain the illustration on the interaction between the visualization process and the numeric data transformation within the experiment and the simulation toward the direction of the visual information (Grave \& Le Lous, 1994:12). The data were gathered by means of forum group discussion with the readers of the urban women magazine in Jakarta. Then, the samples were collected by means of purposive sampling technique; through the purposive sampling technique, the sample collection was adjusted to the needs of the study. In addition to the data gathering activities, the researcher also conducted an in-depth interview with the representative readers in accordance to the characteristics of the targeted readers of female magazines. The interview was conducted in both the structured and the unstructured manner by means of informal conversation with the informant in order to uncover the informant perspective with regards to the perception of the informant on the readership of the printed magazine and the digital magazine.

\subsection{Data Analysis Method}

The descriptive analysis on the data that had been gathered from the readers with regards to the components of the user interface was compared to the results that had been gathered from the questionnaire. The comparison was conducted through the test on the design elements of the Femina Magazine readers. As a result, the researcher would attain the user interface design that might be appropriate for the Femina Digital Magazine readers.

\subsection{Data Collection}

The data had been collected based on the relevance to the objective of the study. The researcher considered that the data had been sufficient when the data had been able to meet the needs of the study. Then, the analysis on the data that had been gathered covered the following aspects:

a. Analysis on the Aspects of the components of the design element from the Femina Digital Magazine readers

b. Analysis on the Aspects of the components of user interface from the Femina Digital Magazine readers.

\section{Results and Discussions}

Mass communication is a process in which the media organization creates and transmits the messages that are desired to be delivered in order to be retrieved, be used and be consumed by the public (John \& Foss, 2009:405). Rakhmat (1994:189) has summarized several definitions from the experts into a single statement as follows: mass communication is a communication that has been targeted toward dispersed, heterogeneous and anonymous community by means of printed or electronic media so that the same message might be retrieved in the same time by the people within the community. 
Meliono \& Budianto (2004:133) state that media have been established due to the mass desires and needs toward information, imagination and high technology. Mass media indeed have influenced the life of mankind and society and have also been the part of the daily life. Therefore, media do not only serve as the source of information but also the source of entertainment especially for the working individuals since these individuals have been working the whole day. In fact, mass media might serve as the bridge to the outside world. In relation to the statement, for the users of cultural media, the constant interaction with the media might lead to the change and the transformation of identity. The magazines in Indonesia - especially the ones that have targeted the female readers - have been proven to serve as a kind of role model for the Indonesian women. Such situation is also found in Femina, which has been claimed as the first female magazine in Indonesia. Since the very first publication, Femina has led the Indonesian women to attain the desired information and imagination.

The digitalization process also brings about good impact on the media industry. The reason is that the digitalization process does not only result in good text layout but also enables an easier, faster and more effective manner for saving media text. When the media text is converted into the digital form, the producers might easily add and create new version or another version from the original version of the media text.

There are two dominant perspectives between the era of the first media, with its implementation on the broadcast, and the era of the second media, with its implementation on the network. The two dominant perspectives are the social interaction approach and the social integration approach (Holmes, 2005:10). The social media approach differentiates the media in accordance to the proximity of the face-to-face interaction model. The outdated model, namely the broadcast model, puts more emphasis on the information dissemination, which decreases the chance of interaction. On the contrary, the novel media, namely the digital media, is more interactive and is able to provide new understanding about personal communication.

The idea of McLuhan in Van Eymeran (2014:44-65) does not discard the old perspective, namely that magazine only serves as news messenger, but he adds that the content of the media might be understood by means of the role and the character of the media until the point of disclosing the meaning that has been represented. According to McLuhan, understanding media is the entry to view the cultural development from one era to another. With regards to the statement, the birth of electronic media has caused mankind to attain different self-understanding and surrounding-understanding. The post-modern mankind is in the culture that has been generated by the rapidly progressive advancement in the domain of technology. The technological advancement has been marked by the invention of printing machine with the typography from the phonetical alphabet. As a result, all of the other senses should be activated and should be functioned under a harmonious unity in order to retrieve the message that has been delivered through the electronic world. In other words, understanding the message through the electronic world means understanding the new world that mankind has encountered since, according to McLuhan, the essence of technology is that technology serves as the extension of the human body itself.

Technological revolution has brought about changes on attitude, trust and existing values. the changes from the literature media on the printing machine into the literature media on the digital machine refers to the change on the form of communication media. Such change on communication media demands sensory adaptation on the part of the content or message receivers. According to McLuhan, within the adaptation process culture shock usually takes place (Van Eymeren, 2014:7-8).

Similar situation also takes place when the printed magazine is converted into the digital magazine. The perspective of the people in the era of printed media culture consists of certain characteristics; for example, people in this era view that all matters are continuous, uniform, explicit and fragmented in time and space. Such characteristic comes from the visual capacity that - in dealing with and observing the printed and the digital media - takes an appropriate angle. On the contrary, in the new and configurative perspective, the media function becomes clearer: since media is the message itself, media has certain characteristics that elicit and control the form of mankind association on the scale of their time and space. With regards to the statement, McLuhan states that it is highly important to keep paying attention to the "content" of the media, but understanding the media from the role and the character might lead an individual to the disclosure of the meaning that the media has represented (Van Eymeren, 2014:47).

The contribution made by McLuhan is the multidimensional explanation about the "medium" through the manner of understanding the social relationships that have been established technologically and that has different reality or ontology. The layers in the technology universe intensify the works in the form of meaning processing that directs the customers to be sunken into the different medium (Holmes, 2012:85-86). Departing from the understanding, the digitalization process also brings about good impact to the media industry because, once again, the digitalization process does not only result in better quality of text media but also enables easier, faster and more effective manner in saving the text media. When the text media is converted into the digital media, a producer might easily add and create new version or another version from the original version of the text media. There are two dominant perspectives between the era of the first media, with its implementation on the broadcast, and the era of the second media, with its implementation on the network. The two dominant perspectives are the 
social interaction approach and the social integration approach (Holmes, 2005:10). The social media approach differentiates the media in accordance to the proximity of the face-to-face interaction model. The outdated model, namely the broadcast model, puts more emphasis on the information dissemination, which decreases the chance of interaction. On the contrary, the novel media, namely the digital media, is more interactive and is able to provide new understanding about personal communication. The idea of McLuhan in Van Eymeran (2014:44-65) does not discard the old perspective, namely that magazine only serves as news messenger, but he adds that the content of the media might be understood by means of the role and the character of the media until the point of disclosing the meaning that has been represented. According to McLuhan, understanding media is the entry to view the cultural development from one era to another. With regards to the statement, the birth of electronic media has caused mankind to attain different self-understanding and surrounding-understanding. The postmodern mankind is in the culture that has been generated by the rapidly progressive advancement in the domain of technology. The technological advancement has been marked by the invention of printing machine with the typography from the phonetical alphabet. As a result, all of the other senses should be activated and should be functioned under a harmonious unity in order to retrieve the message that has been delivered through the electronic world. In other words, understanding the message through the electronic world means understanding the new world that mankind has encountered since, according to McLuhan, the essence of technology is that technology serves as the extension of the human body itself.

Technological revolution has brought about changes on attitude, trust and existing values. the changes from the literature media on the printing machine into the literature media on the digital machine refers to the change on the form of communication media. Such change on communication media demands sensory adaptation on the part of the content or message receivers. According to McLuhan, within the adaptation process culture shock usually takes place (Van Eymeren, 2014:7-8). Similar situation also takes place when the printed magazine is converted into the digital magazine. The perspective of the people in the era of printed media culture consists of certain characteristics; for example, people in this era view that all matters are continuous, uniform, explicit and fragmented in time and space. Such characteristic comes from the visual capacity that - in dealing with and observing the printed and the digital media - takes an appropriate angle. On the contrary, in the new and configurative perspective, the media function becomes clearer: since media is the message itself, media has certain characteristics that elicit and control the form of mankind association on the scale of their time and space. With regards to the statement, McLuhan states that it is highly important to keep paying attention to the "content" of the media, but understanding the media from the role and the character might lead an individual to the disclosure of the meaning that the media has represented (Van Eymeren, 2014:47).

The contribution made by McLuhan is the multidimensional explanation about the "medium" through the manner of understanding the social relationships that have been established technologically and that has different reality or ontology. The layers in the technology universe intensify the works in the form of meaning processing that directs the customers to be sunken into the different medium (Holmes, 2012:85-86). User interface (UI) design is a term that has been used for describing the layout of a machine or a computer unit that has direct interaction with the user. The design and the draft of the user interface should be given special attention in order that the user interface will draw the interest of the user. Schlatter (2013) provides a number of guidelines for designing an application that might be user-friendly by dividing the guidelines into several useful components as follows:

a. Consistency

Consistency refers to the consistency of the user interface layout.

b. Hierarchy

Hierarchy refers to the arrangement of the hierarchy of interest from the objects that will be contained in the application.

c. Personality

Personality refers to the first impression that has been apparent from the application and the first impression will display the peculiar characteristics of the application.

d. Layout

Layout refers to the position of the elements within an application.

e. Type

Type refers to the typography that has been implemented within an application.

f. Colour

Colour refers to the appropriate use of colours for an application.

g. Imagery

Imagery refers to the use of figures, icons and alike for delivering the information within an application.

h. Control and Affordances

Control and Affordances refers to the elements of the user interface that might be implemented by the users to interact with the system through a screen. 
In relation to the above guidelines, Human Interface Guidelines differentiate the macOS application from iOS, tvOS and watchOS application. Since the focus of the study is macOS application, the design components that the researcher should analyse are as follows

(https://developer.apple.com/design/human-interface-guidelines/macos/overview/themes/):

a. Flexible

People expect that the macOS application becomes intuitive and is able to adapt into their work-path by means of adjustment and flexibility. Many applications offer preferences that might be configured, interface that might be adjusted and alternative manners that might be implemented for completing the duties of the users. For example, Windows might be manipulated based on the size of the data and the interface elements might be adjusted or be repositioned. The task itself might start from toolbar, menu, control, keyboard shortcuts, touch bar, accessibility features and alike. The flexible application facilitates learning process by means of the capacity to be discovered.

b. Wide

High-resolution big screen is typical for most of Mac users and people often expand their workspace by connecting an additional screen. The application might benefit this expansion and thus additional value might be provided by benefitting numerous interface components - such as tab, sidebar, banner and panel - and by supporting the immersive feature such as full screen mode.

c. Able

Mac is very able in dealing with the context of hardware and software. The application might benefit this power to offer numerous features and work-paths that met numerous simple, sophisticated and special needs of the users.

d. Focused

The macOS is designed to keep the current task clear and focused. Visual contrast, translucency and wide drop shadow facilitate the users to differentiate between the active Windows and the inactive Windows. The interface subjects to the related content and control. In overall system, the ornament becomes smooth and appropriate.

Usability is one of the aspects that form a technology. From ISO [4] and the results of a study by Nielsen (2012), it might be concluded that usability refers to the ease of operating a technology from the perspective of the technology user. In relation to the statement, the revolutionary changes on the media form, or the technologization of the media form, is accompanied by the culture shock. The technological revolution has brought about changes on the existing attitudes, trust and values. In addition, the media changes on the communication form demands sensory adaptation on either the message that should be delivered and the content retriever. According to the results of observation by McLuhan, it is in the adaptation process that the culture shock takes place.

In relation to the above elaboration, the pages of Femina Digital Magazine for the overall articles display layout differences in comparison to the Femina Printed Magazine. For example, the page of culinary section in the printed magazine is spread-formed or centred while the page of culinary section in the digital magazine is top and bottom-formed. Another confusion also takes place when the printed magazine is converted into the digital magazine. The perspective of the printed magazine-cultured people displays certain characteristics. One of these characteristics is that the printed magazine-cultured people always views all aspects through continuous, uniform, explicit and fragmented perspective in time and space. 
Table 1. Item-Total Statistics

\begin{tabular}{|l|r|r|}
\hline & $\begin{array}{c}\text { Corrected } \\
\text { Item-Total } \\
\text { Correlation }\end{array}$ & $\begin{array}{c}\text { Cronbach's } \\
\text { Alpha if Item } \\
\text { Deleted }\end{array}$ \\
\hline ITEM 1 & .378 & .861 \\
ITEM 2 & .454 & .857 \\
ITEM 3 & .293 & .863 \\
ITEM 4 & .464 & .857 \\
ITEM 5 & .478 & .856 \\
ITEM 6 & .525 & .855 \\
ITEM 7 & .391 & .860 \\
ITEM 8 & .534 & .854 \\
ITEM 9 & .521 & .855 \\
ITEM 10 & .426 & .858 \\
ITEM 1 & .467 & .857 \\
ITEM 12 & .625 & .850 \\
ITEM 13 & .630 & .849 \\
ITEM 14 & .398 & .859 \\
ITEM 15 & .453 & .857 \\
ITEM 16 & .499 & .855 \\
ITEM 17 & .508 & .855 \\
ITEM 18 & .453 & .858 \\
\hline
\end{tabular}

Based on the results in Table 1, it is apparent that several items still have low mean score although in general the mean score has already been high. The items that have low mean score are ITEM 1 ("Digital magazine similarities from one page to another"), ITEM 14 ("Readers are easy to remember the command sequence in the digital magazine") and ITEM 16 ("Readers easily remember what they have done when they are reading the digital magazine"). Then, there are also several items that might be worth considered for evaluation and improvement. These items are ITEM 7 (The command that has been sent into the page is easy to understand and apply), ITEM 8 (The sequence command that has been performed on the digital page is already in accordance to the needs of the readers), ITEM 11 (The error mechanism on the digital magazine screen can be found easily), ITEM 12 (The Return shortcut or button to the previous menu is easy to operate), ITEM 13 (The readers easily operate the button with the new menu) and ITEM 15 (The readers are easy to remember the command sequence in the digital magazine).

\section{Conclusions and Suggestions}

The transition from the printed magazine to the digital magazine is one of the technological revolutions that have been developing in the media nowadays. In relation to the statement, Femina Magazine that has been delivering information for the Indonesian women since 1972 becomes one of the information-sharing tools for the Indonesian women especially in the domain of fashion. The urban women in Jakarta have selected the media not only due to the interpersonal and emotional reason but also their needs in using the media. According to the results of the Focused Group Discussion (FGD), the presence of both the digital media user identity and the printed media user identity is in accordance to the user capacity and also the user needs. Then, departing from the FGD the readers have accepted the Femina Digital Magazine in terms of user interface. However, there are several aspects that should be improved in accordance to needs of the Femina Digital Magazine readers. The improvement should be pursued in order that the Femina Digital Magazine might gain competitive edge from the aspect of technology in comparison to the other digital magazines. The improvement itself has been strengthened by the findings in the study since the findings suggest that the Femina Digital Magazine should develop better and more acceptable user interface. By doing so, the readers of Femina Digital Magazine might be more comfortable in using the new design of the digital magazine.

\section{List of References}

El Ghiffary, Susanto \& Herdiyanti. (2018). “Analisis Komponen Desain Layout, Warna, dan Kontrol Pada Antarmuka Pengguna Aplikasi Mobile Berdasarkan Kemudahan Penggunaan,” Jurnal Teknik ITS.

Holmes, D. (2005). Communication Theory: Media, Technology, and Society. London: Sage.

Holmes, R. (2012). “The Philippines in 2011.” Philippine Political Science Journal.

International Standards Organization. (1998). "Part 11: Guidance on usability ISO 9241-11." Ergonomic requirements for office work with visual display terminals (VDTs).

Irwanto. (1998). Focus Group Discusion (FGD): Sebuah Pengantar Praktis, Pusat Kajian Pembangunan 
Masyarakat. Jakarta.: Universitas Katolik Atma Jaya

Jalaludin, R. (2011). Psikologi Komunikasi. Bandung: PT Remaja Rosdakarya.

Japarianto, E. \& Sugiharto, S. (2011). "Pengaruh Shopping Life Style dan Fashion Involvement Terhadap Impulsif Buying Behavior Masyarakat High Income Surabaya." Journal Manajemen Pemasaran.

Jewitt, C. \& Rumiko, O. (2001). "Visual Meaning: a Social Semiotic Approach." In Theo van Leeuwen dan Carey Jewitt (ed.). Handbook of Visual Analysis. London: Sage Publications.

Jones, K., (2012). Looking at Mode Through Green-Colored Glasses: A Multimodal Critical Analysis of Vogue's. Dissertation.

Koentjaraningrat. (1980). Beberapa Pokok Antropologi Sosial. Jakarta: Dian Rakyat.

Kress, G. Van Leeuwen, T. (2006). Reading Images: The Grammar of Visual Design, Second Edition. New York: Routledge.

Kuntowijoyo. (1997). "Menuju Ilmu Sosial Profetik." Republika August $7^{\text {th }}$, 1997. Jakarta.

Leeweun, T. (2005). Introducing Social Semiotics. New York: Rouledge

Lemke, J. (1990). Talking Science: Language, Learning and Values. Norwood: Ablex Publishing Corporation.

Littlejohn,S. dan Foss, K. (2009). Teori Komunikasi: Theories of. Human Communication. Jakarta: Salemba Humanika.

Marks, H. R. \& Kitayama, S. (1991). "Culture and the self: Implications for Cognition, Emotion and Motivation." Psychological Review.

Marshall, P. D, (2004). "Forms of Interactivity; the Disappearance of the Audience." P. D. Marshall (Ed.). New Media Cultures London: Hodder Headline.

McCracken, E. (1993). Decoding Women's Magazines: From Mademoiselle to Ms. London: MacMillan.

Meliono, I. \& Budianto. (2004). Ideologi Budaya. Jakarta: Yayasan Kota Kita.

Nielsen, J. "Nielsen Norman Group" 2012. [Online]. Available: https://www.nngroup.com/articles/usability-101introduction-to-usability/.

Nurlifa, A. (2014). "Analisis Pengaruh User Interface terhadap Kemudahan Penggunaan Sistem Pendukung Keputusan Seorang Dokter." Prosiding STATIF ke 1 tahun 2014.

Santana, S. K. (2005). Jurnalisme Kontemporer. Jakarta : Yayasan Obor Indonesia, 93-97.

Schlatter, T. \& Levinson, D. (2013). Visual Usability: Principles and Practices for Designing Digital Applications. Elsevier. 